\title{
HISTORY OF HEMATOLOGY AT THE CHARLES UNIVERSITY, FACULTY OF MEDICINE AND FACULTY HOSPITAL IN HRADEC KRÁLOVÉ
}

\author{
Ladislav Chrobák, Milan Bláha
}

\begin{abstract}
Acknowledgements
The origin of hematology as a speciality at the Faculty Hospital in Hradec Kralové goes hand in hand with the establishment of the Department of Internal Medicine at the newly founded Faculty of Medicine. According to the repeatedly declared and broadly accepted concept of the International Society of Hematology, the speciality of hematology comprises two integral, closely interconneted and mutually indivisible components, i.e. clinical and laboratory hematology. It was in accord with these principles that the speciality of hematology was being formed at the Faculty Hospital. When I was approached by the editors of Acta Medica (Hradec Králové) to capture the historical milestones of hematology at the Faculty Hospital in an article, I realized first of all, how demanding this task would be, at the same time I understood I am the only witness of the development of hematology nearly from 1945 till present, which makes it reletively easier for me, compared to my colleagues, to undertake this task. The resulting article originated thanks to active contributions of hematologists from the Department of Clinical Hematology and the Second Department of Internal Medicine who were active participants in the development of hematology. I am sincerely grateful for all their help. I would like to particularly mention efforts of my co-author Milan Bláha, M.D., Ph.D., Professor of Medicine.
\end{abstract}

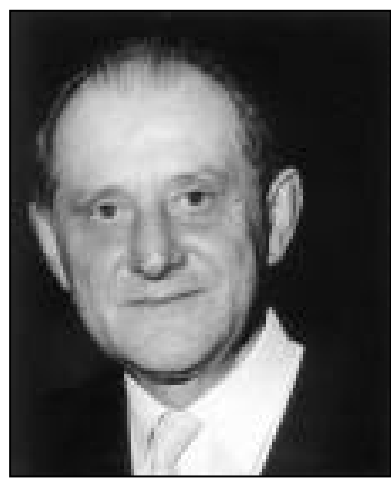

Prof. L. Chrobák (*1927)

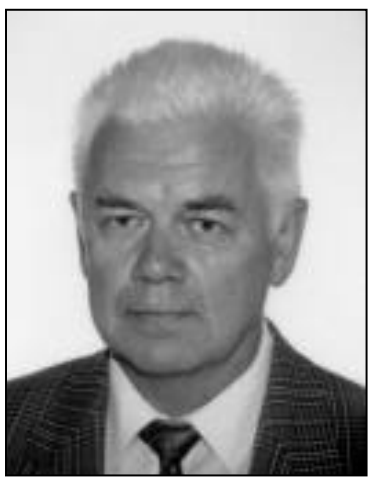

Prof. M. Bláha (*1938)

\section{Introduction}

The following time periods and milestrones in the history of hematology at the Faculty Hospital can be distinguished:

1945-1955 Department of Internal Medicine with a Laboratory of Hematology

1955 - 1997 Division of originally unified Department of Internal Medicine into First and Second Departments of Internal Medicine

1956 Foundation of the Central Laboratory of Hematology located in the building of the First Department of Internal Medicine

1971

$1978 / 79$

1994/IX

1997/X

Establishment of the Department of Clinical Hematology located at the First Department of Internal Medicine with beds for hematological patients as a part of the First Department of Internal Medicine

Foundation of the Unit of Hematological Intensive Care at the Second Department of Internal Medicine

Transfer of the laboratory and outpatient clinic of the Department of Clinical Hematology from the building of the First Department of Internal Medicine into the newly constructed laboratory building with beds for hematological patients still remaining at the First Department of Internal Medicine

Foundation of the new Department of Clinical Hematology with beds for hematological patients in the new Oncology building and joining in this department hematologists from the Department of Clinical Hematology and the Second Department of Internal Medicine

Hematology certainly belongs among the well established and prominent specialties at the Faculty Hospital, and it has become a prominent center on a national level. Hematology began emerging as an independent field at the end of the 19th and at the beginning of this century in step with the progress in laboratory diagnosis, which finally made it possible to diagnose the diseases of the blood. 
Hematology as a specialty, by today's definition, comprises both clinical and laboratory hematology, which according to the International Society of Hematology form a unified and indivisible entity. This principle was meticulously followed by the author during the development of hematology at the Faculty Hospital.

The origins of hematology as a specialty in Hradec Králové are closely tied with the foundation of the Faculty of Medicine (at first as a branch of the Faculty of Medicine of the Charles University in Prague) and with the Department of Internal Medicine. Between 1945 and 1953 when professor Pavel Lukl was the chair of the Department of Internal Medicine, Dr. Josef Procházka (born December 12, 1914) was the hematologist. Dr. Procházka joined the department on March 1, 1946. Professor Lukl appointed him chief of the Laboratory of Hematology. The spectrum of laboratory tests performed at that time was very limited. The tests performed were the complete blood count, bone marrow aspirate evaluation, otherwise osmotic resistance of red blood cells, and as far as coagulation tests are concerned the coagulation time according to Lee White, bleeding time according to Duke, prothrombin time and later the prothrombin consumption test. At first, before the establishment of the Blood Bank, the Blood Group Antigen testing was performed as well. There were few blood donors at that time. Professor Procházka recalls how he at that time, together with the chief of the Blood Bank Dr. Karel Hejna, attended dozens of donor recruitment lectures organized by the Red Cross in bigger and smaller towns of the East Bohemian Region - for free and without travel expenses reimbursement.

In the treatment of Hodkin's disease, leukemias, and polycythemia vera, Dr. Procházka and Dr. Černík began to administer TS160 (trichloromethimium chloratum) a compound analogous to nitrogen mustard, used in the United States in 1946. The drug was obtained thanks to professor Bedrna, the haed of the Department of Surgery in Hradec Králové, from Rybitví. With this is closely related the publication of the monograph Malignant Lymphogranuloma (Hodgkin's Disease) as part of the Thomayer Series (P. Lukl, J. Procházka 1995).

After the takeover of the Faculty of Medicine in Hradec Králové by the army in 1951 and after its renaming as the Purkyně Medical Military Academy, prof. Lukl left in 1953 to join the First Department of Internal Medicine at the Palacky University, Faculty of Medicine in Olomouc, and together with him Dr. Procházka left as well. He later became a professor and devoted himself to the study of coagulation.

Between the years of 1953 and 1955, after professor Lukl had left, Dr. Josef Libánský, Associate Professor of Medicine (born September 3, 1911) was the Head of the Department of Internal Medicine. He came from the University Outpatient Clinic in Prague. Before that he was at the First Department of Internal Medicine of the Charles University, Faculty of Medicine in Prague. He joined the department in Hradec Králové on June 15, 1953. Associate Professor Josef Libánský was at that time already o known hematologist who systematically studied the morphology of blood cells. In 1948 he published his monograph on Cytologic Biopsy of Lymph Nodes, witch represented a cytologic study of lymph nodes. He introduced rigorous monitoring of anticoagulation therapy with Pelentan at the department, which he delegated to Dr. Chrobák. Dr. Ladislav Chrobák (born April 11, 1927) got his medical degree from the Charles University, Faculty of Medicine in Prague in 1951. He joined the department from the Army Officers Reserve Corps School of Health Services in Hradec Králové on October 23, 1953 following a request of Dr. Libánský. Before that he trained for one year at the Department of Internal Medicine in Plzeň under the tutelage of Dr. Karel Bobek, Associate Professor of Medicine.

Almost together with Dr. Libánský joined the department Dr. Ctirad Švehla. Dr. Švehla was already an experienced hematologist, and in addition to performing research of radiation injury he became the chief of the outpatient clinic, while Dr. Chrobák was the chief of the Laboratory of Hematology, and became responsible for its further development. He remained as the chief of the laboratory of hematology until his retirement in 1997. However after two years Dr. Libánský and Dr. Švehla left to Prague. Dr. Libánský became the chair of the in-patient service at the Institute of Hematology and Blood Transfusion, Dr. Švehla joined the Institute for Continuing Medical Education of Physicians in Krč. Associate Professor Libánský was extremely occupied by his administrative duties as a department head, and by his teaching responsibilities. He left the department, before he was able to give it its character of a hematologically oriented department. Dr. Jan Řehoř, Dr.Sc., Professor of Medicine, became the new head of the Department of Internal Medicine. Professor Řehoř was born on May 5, 1895, and had been until then the head of the Department of Internal Medicine in Pardubice. He was the head of the department from 1955 until 1962. Prof. Řehor made the final decision that Dr. Chrobák, who had always been on pursuing cardiology, should become a hematologist.

In June 1955 The Second Department of Internal Medicine was established at the Faculty Hospital. It was formed from the existing Division of Internal Medicine, which had been in existence under the First Department of Internal Medicine already since 1952, and which ensured the teaching of the so called 'Hospital Internal Medicine' at the Purkyne Military Medical Academy. The Second Department of Internal Medicine moved in June 1955 to the reconstructed building on Pospíšil Street, which used to be the Institute for the Hearing and Speech Impaired. Together with the head Dr. Vilo Jurkovič, Associate Professor of Medicine, two hematologists, Dr. Karel Vodička, who then tragically died during an car accident in 1959, and Dr. Jaroslav Mazák, postgraduate research student, left the First Department of Medicine to join the new- 
ly formed Second Department of Internal Medicine. Thus there were in the Faculty Hospital two independent hematologically oriented centers from then on.

The laboratory which existed at the First Department of Internal Medicine, later the Central Laboratory of Hematology and since 1971 The Department of Clinical Hematology $(\mathrm{DCH})$ was the laboratory resource for all the departments of the Faculty Hospital on campus of the so called 'New Hospital'. The Laboratory affiliated with the Second Department of Internal Medicine served mainly as its resource and as a laboratory for the Department of Dermatology, which was located in the same building.

Throughout the time of its existence, the Laboratory of Hematology at the First Department of Internal Medicine met the needs of this Department, and of other departments in the hospital and of the whole East Bohemian Region, for which it served as a consultation center. The staff responsible for meeting these needs until 1971 comprised two physicians of the First Department of Internal Medicine (Dr. Chrobák, Dr. Dagmar Radochová) and Dr. Hana Chrobáková, belonging to the staff of Laboratory of Hematology.

In 1953 the Laboratory of Hematology was represented only by two small rooms on the first floor on the First Department of Internal Medicine, with three technicians. Laboratory methods performed at that time were quite limited.

The complete blood count was done using a counting chamber, hemoglobin level was determined by the imprecise Sahli's method, hematocrit using the Wintrob's hematocrit tubes, platelet count was done by the indirect method from the blood smear according to Fonio. To monitor Pelentan therapy we used even then prothrombin time of the patient compared to a control, at that time not normalized to the international thromboplastin. Because of great variability among batches of commercial thromboplastin, we were making our own thromboplastin from humane brains, which showed lower variability.

\section{Foundation of the Central Laboratory}

In 1956 the Central Laboratory of Hematology was established. In addition to the laboratory at the First Department of Internal Medicine, which became the main laboratory facility, there were other hematology laboratories at the Department of Surgery, Gynecology, Ophthalmology, Ear, Nose and Throat Medicine, and at the Department of Infectious Diseases. Dr. Hana Chrobáková (born July 9, 1927) joined the Central Laboratory of Hematology as a consultant for hematology. She remained in this position until 1971.

In 1959 Dr. Dagmar Radochová (born August 12, 1929) joined the First Department of Medicine. During the longterm absence of Dr. Chrobák, while he worked in Kuwait, she was the acting chief of the Central Laboratory of Hematology and later of the Department of Clinical Hematology.
The spectrum of clinical hematology practiced at the First Department of Internal Medicine included the whole spectrum of diseases, e.i. the diagnosis and therapy of anemias, malignant hematological disorders, disorders of hemostasis and coagulation, including the administration of anticoagulation therapy and later on thrombolytic therapy.

Our papers published on anemias included the monograph 'Paroxysmal Nocturnal Hemoglobinuria' (Chrobák 1967), which was the first monograph on PNH in world literature. PNH was the topic of the author's Ph.D. thesis (1962). Using 51Cr labeled erythrocytes, Dr.Radochová published a number of papers on hemolytic anemias and the role of the hemolytic component in the etiology of anemias associated with leukemias, rheumatoid arthritis, pernicious anemias, and in patients operated in extracorporeal circulation. Her Ph.D. thesis was 'The Contribution of Determination of Survival of 51Cr Labeled Erythrocytes in Anemias of Combined Etiology' (1967).There was close collaboration with the Laboratory of Radionuclides in studies using radionuclide labeling of blood elements.

Citing our literature on anemias, we should mention the paper on Congenital Dyserythropoetic Anemia - Type II (CDA - Type II: HEMPAS) in three siblings with improvement following splenectomy (Chrobák 1975) and the paper on microangiopathic hemolytic anemias (Chrobák 1977). We investigated the pathogenesis of anemia, and its management in patients undergoing dialysis, and we introduced a fairly sensitive test to diagnose graft rejection in allogeneic kidney transplant recipient, based on the detection of erythrocyte fragments in peripheral blood smears (Chrobák, Radochová).

Surgery, with the use extracorporeal circulation of blood was commenced in an experimental model on dogs by Dr. Jaroslav Procházka, Associate Professor of Surgery in 1956, and was introduced clinically in 1958. This type of surgery served as a strong impetus to have available tests monitoring coagulation and hemostasis during and after extracorporeal circulation and for the differential diagnosis of bleeding complications associated with insufficient heparin saturation, with heparin rebound phenomenon, thrombocytopenia, thrombocythopathy, disseminated intravascular coagulation, and pathologically activated fibrinolysis. Series of publications, including 'Coagulation During Extracorporeal Blood Circulation Under Mild Hypothermia' (Associate Professor thesis - Chrobák 1965) resulted in a recommendation of the most suitable series of diagnostic tests for the early detection and intervention in the above mentioned pathologic conditions. Based on the observation that sternotomy alone and extracorporeal blood circulation are conditions that lead to activated fibrinolysis, the cardiosurgery center in Hradec Králové began the prophylactic administration of epsilon - aminocapronic acid in order to inhibit activated fibrinolysis and to diminish blood loss. In connection with hemostasis monitoring during extracorporeal blood circulation, we should mention that a medical student volunteer Josef Pinkas was monito- 
ring, using a fairly simple technique, the defects of platelet aggregation during the extracorporeal blood circulation. His paper (1968) won an award of the American Lung Association, and he received a grand in the United States, where he remained, and specialized in hematology.

The finding that hemophilia is a heterogenous disease, represented by two distinct coagulation disorders: deficiency of Factor VIII (hemophilia A) or Factor IX (hemophilia B) (Aggeler 1952) led to the introduction of the thromboplastin generation test as a more sensitive detection tool for hemophilia. This test allowed the differential diagnosis of hemophilia and the conduction of an epidemiologic study, which mapped hemophilia prevalence in the East Bohemian Region. It was the first mapped region in the Czechoslovak Republic. Thanks to combined efforts of a hematologist (Dr. Chrobák), pediatrician (Dr. J. Polák), rheumatologist (Dr. M. Salavec), and stomatologists (Dr. Z. Antalovská, and Dr. O. Štancl), hemophiliacs in the East Bohemian Region received complex care. These efforts resulted in a number of publications, covering the diagnosis and the most common and most serious bleeding localizations. A hemophilia center was formed, which was later staffed by our hematologists Dr. S. Mirová , and Dr. P. Duliček. Dr. Rudolf Petr, Professor of Neurosurgery, was the first in the world to successfully operate on a brain tumor in a patient with hemophilia (Petr, Chrobák 1969). Later on, determination of levels of factors VIII and IX, and detection of circulating antibodies against factor VIII were performed. The laboratory diagnosis of von Willebrand disease was also improved (Mgr. Foralová, Dr. Dulíček). The introduction of tests measuring levels of factors of the prothrombin complex led to a series of publications devoted to their role in the diagnosis of liver diseases (Dr. Nerad in collaboration with Dr. Chrobáková). This topic became Dr. Nerad's PhD thesis 'On the Issue of Prothrombin Complex' (1964). A very important role in the introduction of coagulation tests was played by our technicians Mrs. Dagmar Hnízdová and Mrs. Jana Nekolová. Papers covering the issue of coagulation include the detection of a heparin type circulating antibody in Wegener's granulomatosis (Chrobák 1987). The most frequently cited paper was on the coagulation properties of human thoracic duct lymph (Chrobák 1967). It became a fundamentally cited paper even in monographs and textbooks.

The investigation of qualitative and quantitative cellular composition of human lymph was pursued by Dr. Radochová (1976) and in patients with malignant lymphomas by Dr. Chrobák (1976). A great deal of effort was devoted to care for patients with leukemia and malignant lymphomas. We conducted research on therapy in patients with chronic myelogenous leukemia in blast crisis (Chrobák). We also had a special interest in Hairy Cell Leukemia (HCL). Our department and the department in Olomouc (Associate Professor B.Wiedermann and Dr. K. Indrák) independently reported the first cases of this pecu- liar disease in the Czech Republic (1974). Throughout the years we detected 55 cases of HCL. Our literature on HCL covered the diagnosis, differential diagnosis, and therapy, which includes splenectomy, administration of interferon alpha and recently 2-chlorodeoxyadenosine. Other publications dealt with trepanobioptic findings, their diagnostic relevance, non-invasive markers of tumor mass and disease activity, levels of soluble IL-2 receptor (sIl-2R), red cell distribution width (RDW), and dyserythropoietic changes in bone marrow (Chrobák, Žák, Podzimek).

\section{Foundation of Department of Clinical Hematology}

The Department of Clinical Hematology (DCH) was established in 1971 in harmony with the national guidelines, It remained located in the building of the First Department of Internal Medicine. The DCH was over time designated more space. The in-patient care was provided thanks to the leadership of the department on 14 beds belonging to the First Department of Internal Medicine. Dr. Chrobák became the chair of DCH, but remained a staff physician at the First Department of Internal Medicine. Dr. Radochová became the vice-chair of the department, and was succeded by Dr. Voglová after the former's retirement in 1990 .

When the Central Laboratory of Hematology received the status of $\mathrm{DCH}$, it was possible to hire more physician staff. The newly formed department was joined by Dr. Soňa Mirová (born May 5, 1945), who took over the responsibilities of leading the Center For Hemophiliacs, Dr. Jaroslava Voglová (born October 12, 1953), who under national and international cooperation efforts concentrated on the diagnosis and treatment of myelodysplastic disorders, especially chronic myelomonocytic leukemia,diagnosis and treatment of chronic myelogenous leukemia and therapy of acute leukemias. In 1990 the department was joined by Dr. Petr Dulíček (born October 10, 1963) and Dr. Pavel Žák (born July 6, 1966), in 1993 by Mgr. Ilona Foralová, and in 1995 by Dr. Vladimír Maisnar (born July 7, 1963). All staff physicians and also Mgr. Foralová are board certified in hematology and transfusion medicine. In addition to their duties in the laboratory and hematology outpatient clinic, all physicians rotated through the in-patient hematology service at the First Department of Medicine. This ensured the closest inter-connections between patient and laboratory services and ensured the best possible global growth of the professional expertise of staff physicians. The growth in the number of staff physicians opened possibilities for their further subspecialization as was demanded by the development of the field of hematology. Dr. Dulíček became interested in disorders of hemostasis and coagulation and in thrombophilic states. He served the chief of the Center for Hemophiliacs. He was the first to report the prevalence of resistance to activated protein $\mathrm{C}$ in the Czech Republic. Dr. Žák became interested in 
certain aspects of HCL, especially in determining the prognostic role of retroperitoneal lymphadenopathy, residual disease and dyserythropoiesis in this disease entity. He gained significant experience and expertise in the placement of permanent catheters and venous port catheters.

Dr. Karel Podzimek (born June 13, 1951) joined the Department of Internal Medicine in 1975. He became interested in lymphoproliferative disorders, CLL, HCL, non Hodgkin's lymphomas, and especially in effective therapeutic approaches towards those diseases.

\section{Transfer of the Laboratory Part and Outpatient Clinic of the Department of Clinical Hematology in to a New Building.}

From the mid 1980s, DCH felt an acute lack of space, which limited further development. At the same time the number of patients coming to the outpatient clinic dramatically increased. Negotiations led by the head of DCH, which lasted years, finally resulted ,thanks to the understanding of the hospital director Dr. Ivan Drašnar, in the transfer of DCH into the newly built Laboratory Building (Fig. 3). This allowed the centralization of equipment and technicians from the whole hospital which translated in increased work efficiency, in acquisition of and in introduction of new laboratory techniques, and by that to increase work efficiency, to acquire new laboratory equipment and to introduce new laboratory techniques, such as electrophoresis of hemoglobin, measurements of thrombocyte aggregation and others. The introduction of hemoglobin electrophoresis and detection of hemoglobin $\mathrm{A}_{2}$ made it possible to diagnose thalassemia minor in 30 patients in the East Bohemian Region. In a mother and a daughter a new unstable hemoglobin which caused hemolytic anemia was identified. The molecular biologic characterization of this defect was performed in the laboratory of Dr. Huisman in

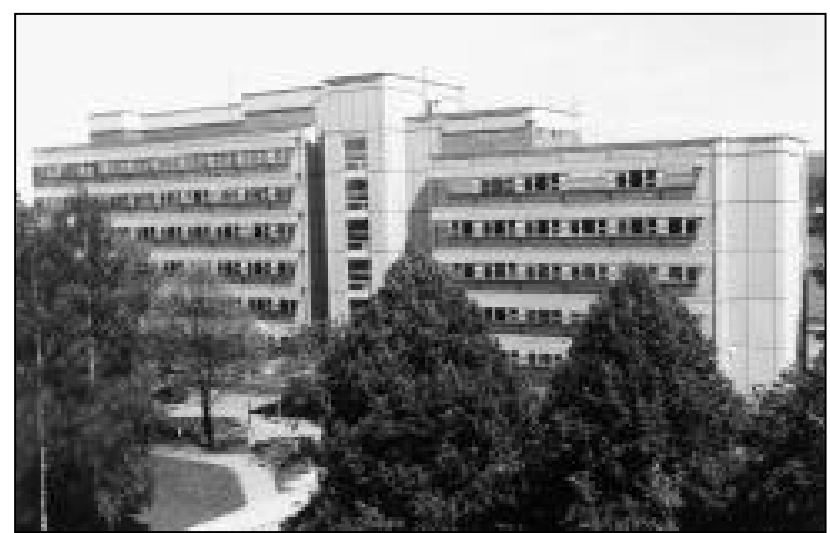

Fig. 3: Building with the Laboratory of Hematology, Department of Medical Genetics and Department of Cardiopulmonary and Vascular Diagnostic in the right wing and Institute of Clinical Biochemistry and Diagnostics and Diagnostic Centre for Internal Medicine in the left wing. (Photo: Alena Žabková).
USA by Dr. Divoký and Dr. Indrák. This new unstable hemoglobin was named Hradec Kralové. Dr. Chrobák’s clinical expertise gained during his two stays in Kuwait led to the diagnosis of these disorders. Dr. Chrobák from 19701971 established in Kuwait the first laboratory of hematology in the Al Sabah Hospital. From 1982 to 1984, as the first Professor of Hematology at the newly founded Kuwait University Medical School he established, the Department of Hematology in the Mularak Al Kabeer Hospital.. In collaboration with Dr. Peter Jarolím, Professor of Medicine, who is the current director of the Institute of Hematology and Blood Transfusion in Prague, four membrane variant defects in patients with hereditary spherocytosis were identified in the laboratories at Tufts University in Boston. These were called Hradec Králové I, Náchod, Jablonec, and Trutnov.

The spectrum of laboratory tests for detection of thrombophilic conditions was enriched. Already in 1979 we diagnosed a congenital deficit of antithrombin (first report in Czechoslovakia) leading in the patient to thrombosis of mesenteric veins (Dr. Tichý, and Dr. Radochová). Between 1991and 1995 we introduced diagnostic tests for lupus anticoagulans, protein $\mathrm{C}$, protein $\mathrm{S}$ and $\mathrm{D}$ dimers (Mgr. Foralová, Dr. Dulíček). The outpatient clinic schedule greatly improved. We were able to see patients every day of the week with three different examination rooms available. In addition to the regular outpatient clinic schedule, clinics for oncohematologic patients, for evaluation and dispensation of patients with hypercoagulable states, and for hemophiliacs and hypocoagulable states were running simultaneously. There were rooms for intravenous administration of blood and blood products, and for chemotherapy. The introduction of computerized record keeping in the clinic and in the laboratories of $\mathrm{DCH}$, thanks to efforts of Dr. Voglová, improved the quality of record keeping and simplified processing of claims for insurance companies.

Prior to June 1, 1997, when DCH merged to form the new Department of Clinical Hematology with its own independent in-patient service with Dr. Jaroslav Malý, Professor of Medicine, as its head, the staff of DCH included its chair professor Chrobák, the vice-chair Dr. Voglová, four other staff physicians, one pharmacist, twenty one technicians, four nurses, and two administrative staff.

\section{Development of Hematology in the Second Department of Internal Medicine}

Development of hematology as a specialty at the Second Department of Internal Medicine was somewhat different. The First Department of Internal Medicine was from the beginning a referral center for the East Bohemian Region. Later on, at the end of the 1970s, the Second Department of Internal Medicine took over patient from one part of this area. The First Department of Internal Medicine provided the hematology consultation service for all the departments on campus of the 'New Hospital', in- 
cluding the Department of Gynecology and Obstetrics, where cases with bleeding and thromboembolic complications were managed, while the Second Department of Internal Medicine provided the consultation service for the Departments of Dermatology, Neurology, and Orthopedics. The number of patients seen at the First Department of Internal Medicine was therefore much higher and the spectrum of hematologic disorders seen broader. The Second Department of Internal Medicine, which was part of the Purkyně Military Medical Academy, had as one of its goals, research of radiation injury mechanisms, and other military internal medicine research projects. It had the advantage of superior funding, coming out of army budget.

Dr. Jaroslav Mazák (born June 29,1925) was the chief hematologist at the Second Department of Internal Medicine. Dr. Mazák got his medical degree from the Faculty of Medicine Charles University in Prague. He became interested in the radiation hemorrhagic syndrome. In his Ph.D. thesis (1959), he showed that the underlying cause of this syndrome is thrombocytopenia caused by marrow aplasia and not, as had been speculated before, an increased anticoagulation activity such as hyperheparinemia or a coagulation factor defect. In his publications, including his Associate Professor thesis, he investigated the radiation syndrome. He showed a suppressive effect on primary hemostasis, which he attributed to altered platelet function. Another problem addressed by dr. Mazák and by the Department of Field Internal Medicine, in this case experimentally in dogs, was disseminated intravascular coagulation. He investigated the effect of heparin and streptokinase on the course of disseminated intravascular coagulation and in shock triggered by intravenous administration of thrombin. He was one of the first in Czechoslovakia to use streptokinase in the treatment of venous thrombosis and in chronic arterial obstruction. He introduced at the department the trepanobiopsy according to Waitz. Dr. Mazák became a professor in 1972. Between 1968 and 1978, when he was the head of the Second Department of Internal Medicine, he tried to support the development of hematology.

Between 1959 and 1973 dr. František Matěja (born October 7, 1926) was at the Second Department of Internal Medicine as an Assistant Professor. He laid the foundations of the laboratory of immunochemistry, by introducing immunoelectrophoresis of blood proteins and the detection of immunoglobulins. The laboratory later on profited from the expertise of dr. Miloš Tichý, Ph.D., Associate Professor, who made this laboratory an outstanding one. Dr. Matěja was also interested in studying cellular and humoral immunity in patients with CLL He paid a special attention to the issue of paraproteinemias and multiple myeloma. In 1973 he became the chief of the Department of Internal Medicine at Rychnov nad Kněžnou. He remained interested in hematology and in 1981 he was chosen to become the head of the Department of Clinical Hematology in the Faculty Hospital of St. Anne in Brno.
In 1960 Dr. Jaroslav Vaňásek joined the Second Department of Internal Medicine. Dr. Vaňásek (born August 18, 1927) got his medical degree from the Faculty of Medicine of Masaryk University in Brno in 1951. Between 1963 and 1969 he was an Assistant Professor, and from 1969 to 1971 he was the vice-chair of the Department of Field Internal Medicine. In his research, starting with his Ph.D. thesis 'Contribution to Studies of Hematologic Changes in Burns Combined with Ionizing Radiation Damage' (1966), and also in his Associate Professor thesis 'Marrow Hematopoiesis in the Course of Experimental Burns' (1971), he investigated hematologic changes in patients with burns. He introduced a technique of standardized burn injury in dogs, which served as a model system to study the pathogenesis and treatment of anemia in burn injuries. Results of these studies were obtained using ${ }^{51} \mathrm{Cr}$ and ${ }^{59} \mathrm{Fe}$ radionuclide assays. He introduced cytochemistry as a laboratory tool at the department, and shared his expertise with colleagues at the Institute of Hematology in Strasbourg, during his stay there in 1967. Because marrow aplasia is to a certain degree a model of radiation injury, he became interested in treatment strategies in patients with marrow aplasia, including bone marrow transplantation. He initiated efforts to treat these patients in sterile facilities, and organized the formation of a transplantation team that included clinical hematologists, radiobiologists, microbiologists, epidemiologists, staff of the tissue bank, stomatologists and others. Dr. Vaňásek became a professor in 1981. Other hematologists also played a role in establishing the transplantation program at the Second Department of Internal Medicine, namely dr. Milan Bláha (since 1971) and Dr. Ladislav Jebavý (since 1977). At that time significant progress was achieved in chemotherapy and radiation treatment modalities. It was also found that improved supportive therapy brought a decreased mortality in patients with hematologic malignancies. The Second Department of Internal Medicine was very successful in this respect and introduced as first in Czechoslovakia a number of new therapeutic approaches. In 1972 the Second Department of Internal Medicine opened the Unit of Hematological Intensive Care, equipped with beds under aseptic conditions. In 1974 the department opened its „life island“ unit. Dr. Bláha played an important role in this effort. The „life island“, produced by Chirana, was also patented. Thanks to all the above-mentioned hematologists, the Second Department of Internal Medicine had a solid base for performing marrow transplants. Mortality due to infectious complications and bleeding in patients with malignant hematologic disorders decreased close to the international standard. Professor Vaňásek also initiated the formation of the so-called 'lymphoma committee', which made decisions on treatment protocols in patients with malignant lymphomas by a process involving participation of radiation therapy physicians. In 1988 professor Vaňásek left to join the Institute of Hematology and Blood Transfusion in Prague. Between 1988 and 1991 he became the chief of the clinical service of the department 
there, and between 1991 and 1994 he was an investigator in the institute. When he joined, the institute started a bone marrow and peripheral stem cell transplantation program. He made an essential contribution to its development. He was the chief author of a monograph „Bone Marrow Transplantation", which received the award of the Literary Fund in 1996.

Dr. Milan Bláha (born June 6., 1938) joined the Second Department of Internal Medicine in 1971. He was interested in the issue of complex supportive care under aseptic conditions in immunocompromized patients. The introduction of the separator of blood elements is linked with his name. This brought with it the possibility to obtain high quality platelet and granulocyte concentrates. This was also the subject of his Associate Professor thesis „Separators of Blood Elements as a Modern Component of Prevention and Therapy of Certain Disorders of Hematopoiesis“ (1980). This issue was also discussed in his monograph „Supportive Care in Marrow Failure (1985). The publication covered in a complex manner prevention of infections, complications, reverse isolation, and total and selective decontamination of patients. In indicated cases Dr. Bláha also performed therapeutic hemapheresis (red cell apheresis, leukapheresis, thrombocytapheresis) and therapeutic plasmapheresis. The Center of Hemapheresis led by him belongs to the most experienced in the Czech Republic and it performed the highest number of separations. The Second Department of Internal Medicine and its hematological team were successful in the treatment of bleeding due to thrombocytopenia by administration of platelet concentrates. Prevention of exogenous infections became successful thanks to the method of reverse isolation. Endogenous infections however remained a problem world-wide. The so called total decontamination of endogenous bacterial flora was attempted, but hematologists of the Second Department of Internal Medicine did not have positive experience with this approach. Professor van Bekkum introduced the method of selective decontamination of potentially pathogenic flora. Thanks to good contacts of the Second Department of Internal Medicine with hematologists in Rostok, it was possible to apply this method soon.

Selective decontamination of the gastrointestinal tract with proposals for appropriate therapeutic approches was covered in publications, and Ph.D. thesis (1989) of Dr. Ladislav Jebavý (born May 5, 1950). He joined the Second Department of Internal Medicine in 1977 and has been in the Unit of Hematological Intensive Care since. He became the chief of this service in 1991. In 1994 Dr. Jebavý received the degree of Associat Professor after defending his thesis „Utilization of Hematopoietic Frowth Factors in Clinical Practice“.

Dr. Bláha and Dr. Jebavý studied radiation injury disease using as a model patients with certain hematological disorders.

In 1990 Dr. Miloslav Kmoníček (born February 21, 1966) joined the Second Department of Internal Medicine and became interested in autologous transplantation in malignant lymphomas and multiple myeloma. His Ph.D. thesis covered the issue of indications of platelet concentrates in patients with acute myeloid leukemia on chemotherapy (1998). The hematology team at the Second Department of Internal Medicine included Dr. Oldřich Široký, who was a co-author of several publications on coagulation disorders and malignant hematologic diseases. After the formation of the new Department of Clinical Hematology, he remained at the Second Department of Internal Medicine.

RNDr. Miroslav Pecka (born April 1, 1947) joined the Second Department of Internal Medicine in 1976. As a chief of the hematological laboratory, he was responsible for its routine service, but also for its developement. From this fact stemmed his collaboration on clinical issues and on a number of research projects at the Second Department of Internal Medicine. Between 1977 and 1980 he introduced the RIA measurement of vitamin B12 levels and procedures for human blood cell tissue culture. Between 1981 and 1991 he was responsible for the performance of coagulation tests in patients with acute medical conditions. He also put together laboratory standard for monitoring antithrombotic therapy.

His significant contribution lies in his research on thrombogenesis, where he introduced the detection of markers of thrombogenesis: PF 4; Beta T6; 1,6 PGF1 alpha1; TX B2 and also in the introduction of tests for adhesion and aggregation of platelets. His Ph.D. thesis was 'Platelets Cytosolic Calcium in Acute Medical Conditions' (1990). His great merit lies in standardization of hematologic laboratory tests in the years of 1991 to 1997 to meet the needs of the Ministry of Health. His laboratory experience led to the publication of his two monographs "Overview of Laboratory Hematology I and II (1995,1996).

Dr. Jaroslav Malý (born December 8, 1946) was profiled by professor Mazák to study the issues of hemostasis and hemocoagulation. He joined the Second Department of Medicine in 1973. His interests can be divided into two areas. The first area of interest are acquired defects of platelets. This was the topic of his Ph.D. thesis „Alteration of Hemostasis in Patients with Renal Insufficiency“ (1981) and also of his Associate Professor thesis 'Significance of Changes of Platelet Functions in Certain Medical Conditions' (1995). He showed distinct increase of platelet function in patients with hypertension, smokers and patients suffring from migrane, even in the absence of an acute attack. This finding has considerable practical implications since it signals an increased risk of arterial thrombosis. He also concentrated on monitoring changes of hemostasis in pre-shock and shock states and in acute hematologic disorders and in disorders such as acute leukemias, bone marrow aplasia and so on. The second area of his interest were thrombophilic states and diagnosis and therapy of disseminated intravascular coagulation. From a clinical point of view, his publications devoted to thromboembolic disease and arterial thrombosis are very valuable. $\mathrm{He}$ is the first to 
report complex experience with streptokinase treatment in this country and he was among the first in Czechoslovakia to publish experience with tPA in acute myocardial infarction. In this context he pointed out the dependence of coronary artery reperfusion on the concentration of fibrinogen. He became a professor in 1996. Both departments DCH and Second Department of Internal Medicine also served as centers of postgraduate training. Almost all chiefs of the East Bohemian Hematology and Transfusion Medicine Departments rotated through the Department of Clinical Hematology service at the First Department of Internal Medicine. Regular regional hematological seminars were a part of continuing education in hematology. Courses devoted to problems in hematology were organized by Department of Clinical Hematology and Second Department of Internal Medicine for physicians and for nurses and technicians.

The Second Department of Internal Medicine became a nation-wide and internationally recognized center for postgraduate training of military physicians. The hematologic group organized regular update courses and national and international meetings of military physicians.

Both departments helped to start professional and scientific careers of number of students, so called student assistant researchers. Some presented their works at national and even international student conferences. Some of them choose to specialize in hematology (Gabriela Cyranyová, Vladimír Maisnar, Josef Pinkas, Karel Podzimek, Karel Vácha, Jaroslava Voglová). The development of hematology would not be possible without close cooperation with specialties that provided information required for both successful diagnosis and therapy. These specialties include microbiology, cytogenetics, diagnostic and therapeutic radiology, transfusion medicine, tissue bank, stomatology and other specialties in the form of consultations.

\section{Bone Marrow and PBSC Transplantation Program in the Second Department of Internal Medicine.}

A special section should be devoted to bone marrow and peripheral blood stem cell transplantation. This is a traditional field in Hradec Králové. Many original important contributions both on a national and international level were made. Hematologists at the Second Department of Medicine became interested in this field and started intensive preparations for its application already in the late $60 \mathrm{~s}$ and in the 70s (in view of the complicated nature of the procedure and difficult conditions at that time) with only a small delay after the first international centers. It was at that time that the first centers using powerful sources of radiation and the use of radiation in industry started. Protection of their personnel became necessary. Research in this area was supported by the army. It was thought at that time that marrow transplantation could be used in the management of nuclear accidents. Expectation rose after, physicists from Yugoslavia following radiation exposure were successfully treated by professor Georges Mathé in Paris 1966. Dr. Rudolf Klen from the Tissue Bank in Hradec Králové (the second tissue bank in the world and the first in Europe) with Dr. Vaňásek and later with Dr. Pavel Měřička and Dr. Bláha started experimental work on the bone marrow harvest and storage program. Work was done on utilization of cadaverous donor marrow. Unique containers for bone marrow were developed in Hradec Králové, and for the first time laminated foils were used for the production of bags for bone marrow. In 1976 the first allogeneic bone marrow transplant was performed under at that time state of the art conditions. Bone marrow was harvested by orthopedic surgeons - Associate Professor Oldřich Fiala and Dr. Karel Urban. At the same time further clinical research was conducted and steps were taken to ensure a successful continuation of the transplantation program. Dr. Bláha, Associate Professor Šulc, and Dr. Kobylka published a paper showing as the first in Czechoslovakia and among the first in the world that cyclophosphamide unexpectedly mobilizes stem cells from marrow into the periphery. Cyclophosphamide remains even today as a „gold standard" priming agent. Clinical application of cyclophosphamide was tested and so shortly after the first use of peripheral blood stem cells in the world, three patients with lymphomas after myeloablative chemotherapy received peripheral blood stem cell transplants as first in Czechoslovakia (1987). The transplantation program was expanded in 1991. Since 1994 the Second Department of Internal Medicine and the Department of Radiotherapy became active members of the European Blood and Bone Marrow Transplantation Group. In 199620 autologous transplants in hematological patients and 14 in patients with solid tumors were performed. In 1997 already 41 transplants were performed and since 1998 allogeneic transplants have been started. In 1998 about 50 autologous and 10 allogeneic transplants in hematologic patients and about 15 in solid tumors are scheduled. The transplantation center in Hradec Králové is very active among the seven transplantation centers in the Czech Republic and it has been performing cord blood stem cell harvest since 1998.

Collaboration with the army remains very important. This collaboration is directed by Associate Professor Jebavý, Head of the Department of Field Internal Medicine of the Purkyně Military Medical Academy. He is also professional vice-chair of the Department. Under his leadership the Transplantation Unit and the Unit of Hematological Intensive care has been designated as an emergency center for the Czech nuclear industry. The appreciation of the hematologic departments in Hradec Králové has been reflected in the delegation of local hematologists into different committees and in the selection of Hradec Králové as a venue of meetings. In 1965 the First Meeting of the Laboratory Committee of the Czech Society of Hematology was held in Hradec Králové. Further meetings of the Czech Society of Hematology were held in Hradec Králové in 
1977 and in 1981 (Chrobák). The IXth National Meeting of the Czechoslovak Society of Hematology in 1987 (Chrobák, Malý) and Trilateral Symposium of Hematologic Societies of Czechoslovakia, East Germany and Poland in Třinec in 1989 (Chrobák) are other example. Hradec Králové is the venue of „laboratory days“ (1995,1996,1998 - Pecka, Malý) since 1995, on a regular basis, very successful Czecho-Slovak conferences devoted to hemostasis and thrombosis are held interchangeably in Martin (prof. Kubisz 1994, 1996 and 1998) and in Hradec Králové (prof. Malý 1995, 1997). Several hematologists from Hradec Králové became members of the Committee of the Czech Society of Hematology: Dr. Chrobák (president and vicepresident), Dr. Malý (vice-president), Dr. Vaňásek (member of the Committee and scientific secretary during his stay in Prague), Dr. Pecka (chair of the Laboratory Section), Mrs. Soňa Kieslichová (member of the Committee for Technical Staff). From 1978 to 1984 Dr. Chrobák was the expert of the WHO for hematology and from 1990 to 1991 he became chief specialist of the Ministry of Health of the Czech Republic for the specialty of hematology until these posts of specialists were abolished.

\section{Foundation of the New Department of Clinical Hematology with the In-Patient Service.}

The existence of two departments of hematology, with an in-patient service at the First Department of Internal Medicine on one hand, and the Second Department of Internal Medicine with a laboratory of hematology on the other hand, equaled to an unnecessary split of resources, expecially scientific and professional. This was clear to hematologists at both departments. Unification was prevented however by space constraints. There was hope

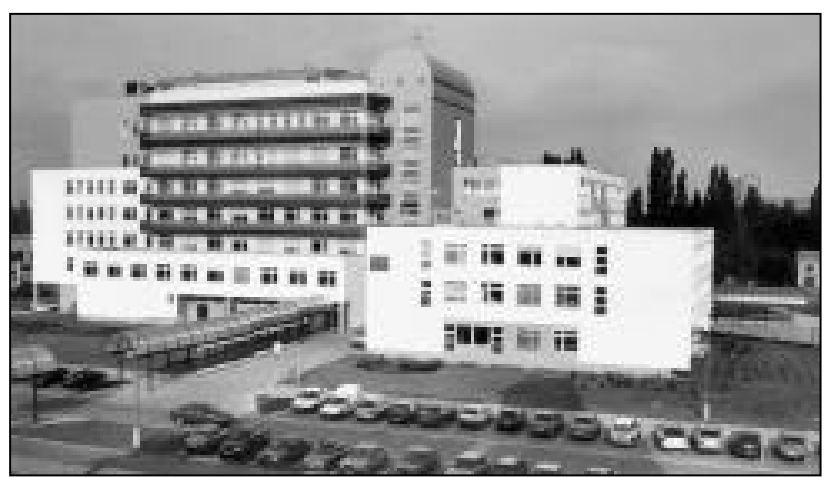

Fig. 4: Baštecký pavilion with the Department of Oncology and Radiotherapy, Department of Clinical Hematology, and Department of Nuclear Medicine (Photo: Alena Žabková). connected with the construction of the new Oncology pavilion in the „New Hospital“, where the capacity would allow the placement of an idependent hematology in-patient service including the outpatient clinic. Following the meeting of hematology chairs (professor Dr. Chrobák and associate professor Dr. Malý) and the head of the Radiotherapy Department (Dr. Jaroslav Vaňásek jr., Ph.D.) in 1993 a proposal along these lines was sent to the hospital director. Arguments for such a proposal included the close linsks between the future Department of Clinical Hematology and Department of Radiotherapy and the possibility of cooperation in the future. It was also in agreement with the intentions of the Faculty Hospital Director Associate Professor Leoš Heger, Ph.D. to concentrate all in-patient care on the campus of the New Hospital. Although the approval of this proposal was not easy to reach, it was in the end approved.

In October 1997 the new constituted Department of Clinical Hematology started its work and professor Dr. Malý became its head (Fig. 4). The department comprises an in-patient service, outpatient clinic, hemapheresis center and a laboratory part which remained in the previous laboraty building. The vice-chair for the laboratory part is RNDr. Miroslav Pecka, Ph.D. The in-patient service comprises 6 transplantation beds, 6 intensive care beds, 4 beds of intermediary care and 29 standard hematology care beds. The hemapheresis center with 5 separators is an integral component of the new Department of Clinical Hematology It can prepare within three hours upon request a platelet concentrate for use within the in-patient service of the department or for any department in the Faculty Hospital. It performs all the other therapeutic procedures (haemapheresis and plasmapheresis and collection of granulocyte concentrates or peripheral blood stem cell) even in patients in serious conditions requiring monitoring of basic life functions. The outpatient clinic has five examination rooms, a procedure room, rooms for blood and blood component therapy and for chemotherapy.

Conditions have thus been created for the new Department of Clinical Hematology to continue successfully in further growth in both clinical care and research, and to fulfill its role as a teaching center for training on both an undergraduate and postgraduate level. The department has all the conditions to become a part of the Medical School like similar centers in Olomouc and Brno.

Prof. MUDr. Ladislav Chrobák, CSc., Department of Clinical Hematology, Charles University, Faculty of Medicine and Faculty Hospital, 50005 Hradec Králové, Czech Republic. 